\title{
Conditioning factors for nurses to defend the autonomy of the elderly on the terminality of life
}

\author{
Fatores condicionantes à defesa da autonomia do idoso em terminalidade da vida pelo enfermeiro \\ Factores condicionantes para el enfermero defender la autonomía del mayor al final de la vida
}

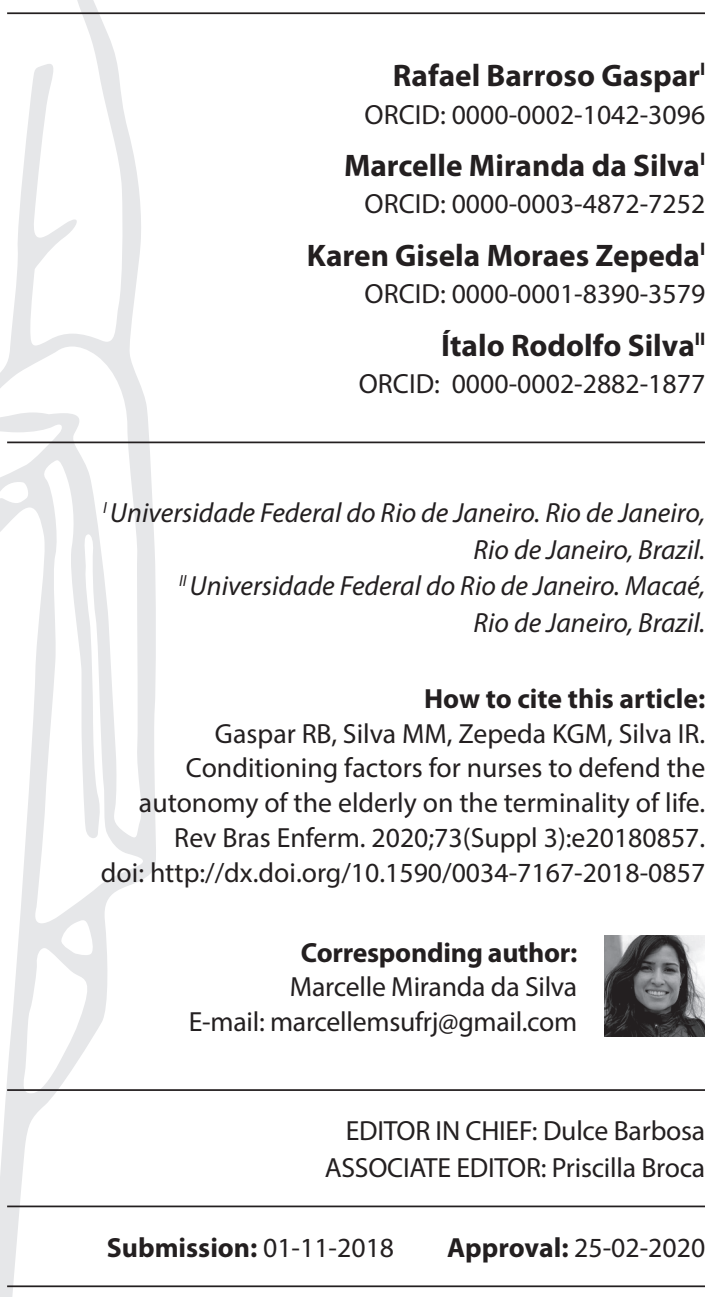

\begin{abstract}
Objective: to understand the meanings attributed by nurses about conditions that interfere in defending of the elderly's autonomy on the terminality of life in the context of hospitalization. Method: qualitative and exploratory study, which applied the Grounded Theory. Data were collected between November 2016 and May 2017, in the internal medicine wards of a hospital in Rio de Janeiro, Brazil, through non-participant observation and semistructured interviews. Three sample groups composed of ten nurses, eight doctors, and 15 nursing technicians were investigated. Results: the conditions are related to the medical power, subordination of nurses, family influences; the functional decline of the elderly; and biomedical model. Final considerations: the elderly's autonomy is veiled and violated since their abilities are subjugated, and the family's will and professional paternalism may prevail. However, this right must guide contemporary care models and integrate palliative care. Descriptors: Nursing; Personal Autonomy; Palliative Care at the End of Life; Elderly Rights; Hospitalization.
\end{abstract}

\section{RESUMO}

Objetivo: compreender os significados atribuídos pelos enfermeiros acerca das condições que interferem na defesa da autonomia do idoso em terminalidade da vida no contexto da internação hospitalar. Método: estudo qualitativo e exploratório, que aplicou a Teoria Fundamentada nos Dados. Os dados foram coletados entre novembro de 2016 e maio de 2017, nas enfermarias de clínica médica de um hospital no Rio de Janeiro, Brasil, por observação não participante e entrevista semiestruturada. Investigaram-se três grupos amostrais compostos por dez enfermeiros, oito médicos e 15 técnicos de enfermagem. Resultados: as condições relacionam-se com o poder médico; subordinação do enfermeiro; influências da família; declínio funcional do idoso; e modelo biomédico. Considerações finais: a autonomia do idoso é velada e violada, uma vez que suas capacidades são subjugadas, podendo prevalecer a vontade da família e o paternalismo profissional. Entretanto, esse direito deve guiar os modelos assistenciais contemporâneos e estar integrado aos cuidados paliativos.

Descritores: Enfermagem; Autonomia Pessoal; Cuidados Paliativos na Terminalidade da Vida; Direitos dos Idosos; Hospitalização.

\section{RESUMEN}

Objetivo: comprender los significados atribuidos por los enfermeros sobre las condiciones que interfieren en la defensa de la autonomía del mayor al final de la vida. Método: estudio cualitativo, exploratorio, que aplicó la Teoría Fundamentada en los Datos. Los datos han sido recogidos entre noviembre de 2016 y mayo de 2017, en las enfermarías de un hospital en Rio de Janeiro, Brasil, por observación no participante y entrevista. Ha sido investigado tres equipos: diez enfermeros, ocho médicos y 15 técnicos de enfermaría. Resultados: las condiciones han sido relacionadas con el poder médico; subordinación del enfermero; influencias de la familia; declive funcional del mayor; y modelo biomédico. Consideraciones finales: la autonomía del mayor ha sido velada y violada, una vez que sus capacidades han sido subyugadas, puede prevalecer la voluntad de la familia y el paternalismo profesional. Mientras, eso derecho debe guiar los modelos asistenciales contemporáneos, integrado a los cuidados paliativos.

Descriptores: Enfermería; Autonomía Personal; Cuidados Paliativos al Final de la Vida; Derechos de los Ancianos; Hospitalización. 


\section{INTRODUCTION}

The possibility of living longer during old age is a worldwide reality. According to the World Health Organization (WHO), "a child born in Brazil in 2015 can expect to live 20 years longer than a child born 50 years ago"(1). With this statistic, the country has a population projection of about 32 million older adults for $2020^{(2)}$.

However, the years added to individuals do not occur evenly due to social and economic inequalities between countries. However, it is undeniable that the increase in life expectancy and the hope of enjoying a more dignified old age represent a social gain never seen in another moment in human history ${ }^{(1-3)}$.

This longevity, in many cases accompanied by the chronicity of some diseases, results from a set of factors, such as the progress of public health and biotechnology policies, which enabled early diagnoses, treatments, and measures to control previously fatal diseases, and have contributed to a new look at medicine and the elderly themselves from the perspective of the process of death and dying. Thus, although the immediate association between old age and death in past moments is gradually losing space, it is necessary to reflect on situations that can compromise the elderly's autonomy.

Autonomy, as a person's right and bioethical principle, can be understood as a mechanism that expresses the freedom of the elderly to act according to their conscience, enforce their social, cultural, and religious values and thus make their decisions, including those concerning their own health treatment. Thus, it is important noting that the progress of a disease, even without therapeutic possibilities for a cure, does not invalidate the decision-making ability of the elderly ${ }^{(3)}$.

However, it is not uncommon when the elderly are hospitalized in situations of dependence, in several health services, there is disregard of their cognitive ability and, therefore, the impossibility of the individual's self-determination concerning their own treatment. In these situations, such an attitude may even compromise other bioethical principles, such as beneficence, non-maleficence, and justice, since age is not an indicator of loss of autonomy ${ }^{(3)}$.

Several factors contribute to the fact that many older adults are in situations of vulnerability: for example, aging itself, which, although it is a natural process, needs to be analyzed under two essential concepts, senescence and senility. The first understood as the set of non-pathological changes resulting from longevity, and the second, as pathophysiological conditions that compromise the quality of life. Although public policies advocate healthy aging, the reality is that the majority of the elderly are affected by chronic noncommunicable diseases (NCDs), which require frequent and prolonged hospitalizations. Such factors can affect the elderly's ability to participate in decisions regarding their own lives and the process of dying ${ }^{(2-4)}$.

The compromised elderly's autonomy during hospitalization leads to submission, even against their will, to certain procedures that will not necessarily bring them the quality of life. Therefore, when the elderly are ill and do not have their own mechanisms to enforce their will, they need the help of someone who defends their rights, such as autonomy for decision-making, physical and psychological integrity, image rights, and privacy in health institutions ${ }^{(4)}$.

We highlight the duty of nurses - based on their theoreticalphilosophical and technical framework, observing the ethical and legal precepts of the profession, present in the Brazilian Code of
Ethics for Nursing Professionals - to respect the right to exercise the elderly's autonomy.

\section{OBJECTIVE}

To understand the meanings attributed by nurses about the conditions that interfere in defending of the elderly's autonomy on the terminality of life in the context of hospitalization.

\section{METHODS}

\section{Ethical aspects}

The ethical aspects of research with human beings were respected, under Resolution 466/2012 of the Conselho Nacional de Saúde (National Health Council). Thus, the research project was approved by the proposing and co-participating institutions, respectively, Anna Nery Nursing School and Clementino Fraga Filho University Hospital. All participants received information about the research and signed the Free and Informed Consent Form. Anonymity was ensured by identifying the interview clippings by alphanumeric codes.

\section{Theoretical-methodological framework}

The Grounded Theory (GT) methodological framework was applied, which is based on the precepts of the Straussian approach. GT aims to reveal the understanding of the multiple phenomena of the nurses' performance scenario from elements such as meanings, opinions, values, and perceptions and, thus, meet the requirements of the object of study $y^{(5)}$.

\section{Type of study}

Qualitative and exploratory study.

\section{Study scenario}

The study was carried out at a university hospital in Rio de Janeiro, Brazil.

\section{Data collection and organization}

Data were collected in internal medicine wards, in the period between November 2016 and May 2017. Following method guidelines, we developed three sample groups. The first sample group consisted of ten nurses who met the following inclusion criteria: working for at least six months in internal medicine wards; and having an employment relationship with the institution. Nurses who worked in exclusively administrative positions and those who were on vacation or leave of any nature during the data collection period were excluded.

Although the study addresses the theme and its implications for nurses, GT is characterized by flexibility in understanding the phenomenon, targeting new sample groups, as evidenced by the hypotheses that arise during data collection and analysis ${ }^{(5)}$. Thus, the data indicated the need to approach other practices, that is, performed by doctors and nursing technicians, who also knew about the phenomenon investigated, due to the strong relationship between their work processes. 
Therefore, the second sample group was composed of eight doctors, one being the internal medicine physician and seven medical residents. The hypothesis referred to the formation of this group was: the doctor is responsible for the prognosis of the elderly and the direction of actions based on palliative care at the end of life, which requires assertive communication to avoid ethical conflicts, barriers in the professional practice of other professionals of the staff and false hopes on the part of the elderly and their families.

Furthermore, the third group was composed of 15 nursing technicians. The hypothesis referred to the formation of this group was: nursing technicians, as the professionals with the most significant contingency and who most establishes contact with the patients and their family in the hospital environment, can identify situations that compromise elderly's autonomy in palliative care at the end of life.

Both met the same inclusion and exclusion criteria established for nurses.

The data collection techniques used were non-participant observation and semi-structured interviews based on the following generating question: What do you understand by the elderly's autonomy on the terminality of life? The interviews were carried out individually, in a private place, at the time of the participants' choice, and recorded after due authorization. The average time for each interview was 30 minutes.

Before the interviews, the professional profile of the participants was characterized, considering the following variables: age, professional category, length of time working in the sector, length of experience in palliative care, and professional qualification.

\section{Data Analysis}

The data were analyzed following the coding steps, namely: open coding, axial coding, and integration. Such steps highlight the analytical process of information in GT, which occurs from the division, conceptualization, and correlation of data. In open coding, the raw data from the transcribed interviews are analyzed line by line, in a microanalysis process, generating preliminary codes $^{(5)}$. In axial coding, preliminary codes are grouped by similarity, forming conceptual codes. Such codes can form subcategories, which will then be grouped into categories, which represent concepts. In the integration stage, the paradigmatic model is applied to reveal the core category or central phenomenon of the study ${ }^{(5)}$.

The paradigmatic model is composed of the following elements: conditioning factors, action-interaction strategies, and consequences. The conditioning factors aim to answer the questions about why, when, and how things happen, in addition to highlighting the reasons and explanations provided by the participants to justify their actions (action/interaction) in the face of what happened. Action-interaction strategies comprise people's responses to certain problems, challenges, or objectives. Such responses result from the meanings attributed to them after perceptions about certain situations. Is it possible to understand the consequences as the results or expectations of certain actions ${ }^{(5)}$.
It is noteworthy that the coding process generated three categories. However, considering the scope and importance of the conditions that can interfere in defending the elderly's autonomy in the context of hospitalization, only one category was detailed in this framing. It refers to the paradigmatic component "conditioning factors," which gathers the reasons participants of the study presented for a certain phenomenon to happen, as well as explanations about why they respond in a certain way in relation to an action.

\section{RESULTS}

Regarding the professional profile of the participants, among the ten nurses, the average age was 39 years old. The average length of time working in the sector was four years, and in palliative care was seven years. Among the eight doctors, the average age was 31 years old, the average length of time working in the sector, and palliative care was four years. Of the 15 nursing technicians, the average age was 45 years old. The average length of time working in the sector was four years, and in palliative care was seven years. Of these professionals, only four nurses, three doctors, and two nursing technicians took refresher courses on palliative care.

Regarding the process of coding and systematic data analysis, the category entitled"Representing the influences of the work process, decision making, and the family on the elderly's autonomy" was developed. This category represents the element "conditioning factors" of the paradigmatic model, which contributed to the definition of the following central phenomenon: Articulating elements of the nursing profession and the profile developed in its practice of hospital care to defend the elderly's autonomy on the terminality of life.

This category consists of four subcategories, one of which has three components, as can be seen in Figure 1.

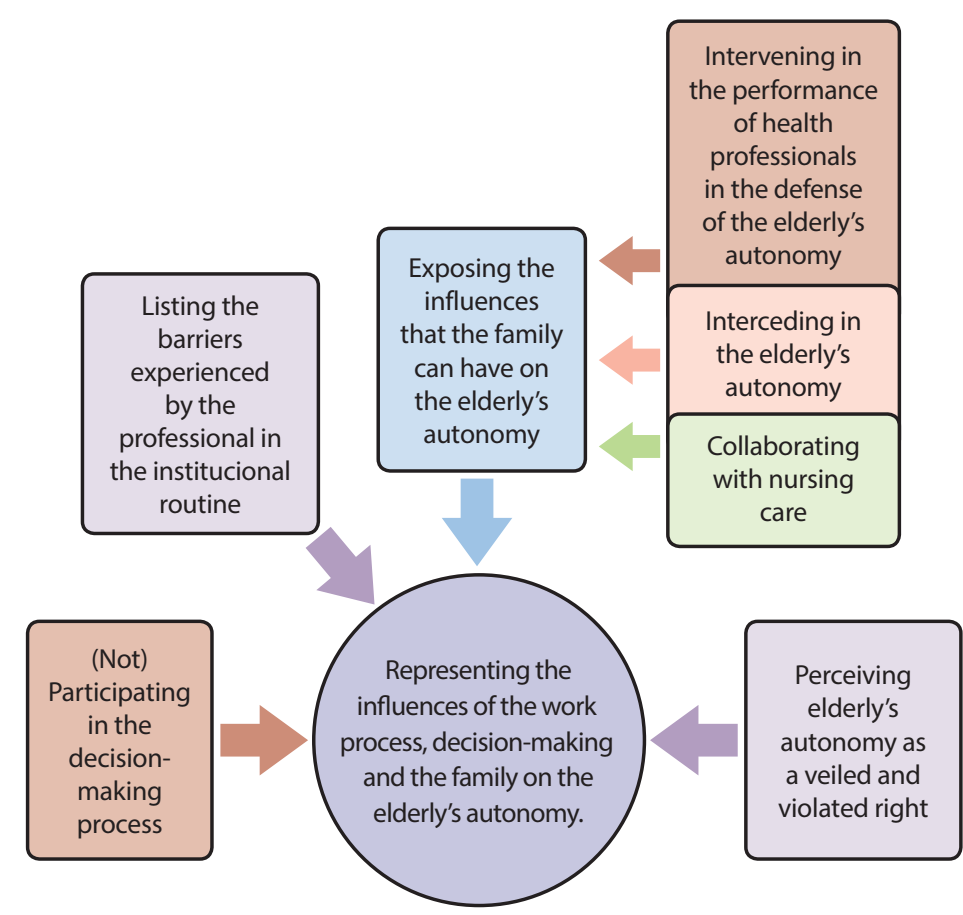

Figure 1 - Representing the influences of the work process, decision making, and the family on the elderly's autonomy 


\section{Subcategory 1 - (Not) Participating in the decision-making process}

This subcategory addresses the participation of nurses in the decision-making process in the transition from curative to palliative care. In general, the study highlighted that they participate little or do not participate in this process, being only communicated by doctors about the decision. Also, we noted that the medical decision interferes with the planning of care by nurses and other health professionals, especially when there is a delay in the patient's recognition in palliative care (Figure 2).

In my service, decision making is basically medical, carried out by staff and other residents who are close to the patient. After the decision has been made, during the change of shifts, it is reaffirmed for nursing and social work that for that patient, only comfort measures can be done. (M6)

Once in palliative care, I see that the nurse makes some decisions doing everything possible to alleviate suffering, especially in the control of symptoms. But also, I often see a great distance from what the patient really needs. (T6)

You need time to analyze the tests to identify whether chemotherapy is palliative or curative. Sometimes we don't even have time to identify this, let alone participate in a round to discuss situations about the patient. We would need more staff. (N9)

I think there are nurses who are sometimes inhibited from having a dialogue with the doctor and exposing the patient's need to help him. I see a lack of dialogue between the nurse and the doctor. I think that dialogue is very important, as it will benefit the patient. (N1)

\section{Field Note 1. Title: Observing the performance of $\mathrm{N} 1$.} Date: 25/09/2016

$\mathrm{N} 1$ took over the night shift and, on a shift change, became aware of the complications. Aware of the information, the professional made the work schedule of the technical nursing staff by ward, a routine of the institution. Then, N1 talked to the staff and explained the priorities, one of which was the pain control of an older woman in palliative care. It was possible to observe the importance of dialogue between the nursing staff for care planning. N1 carried out the nursing visit, prioritizing the patient in pain, and asked the nursing technician to administer an analgesic prescribed for the time. However, in the medical prescription, there was only intravenous medication, and the staff was already aware of the difficulty of peripheral venous access. The staff still tried to perform the puncture, but given the difficulty and the report that the patient no longer wanted to be "pierced," $\mathrm{N} 1$ contacted the medical staff, explained the patient's clinical condition, and requested an evaluation. When the doctor on duty arrived in the sector, $\mathrm{N} 1$ ratified the difficulty of venous access, and even so, the professional tried to puncture the external jugular vein, claiming that the intravenous medication would have a better effect. After no success, N1 proposed to change the route of administration of the drug to subcutaneous, and it was done.

Figure 2 - Field note from non-participating observation

\section{Subcategory 2 - Listing the barriers experienced by the professional in the institutional routine}

This subcategory addresses professional barriers and institutional routines as elements that influence the decision-making process. Concerning professional barriers, it was highlighted that there are professionals who do not have a predilection for working with patients in palliative care, mechanizing assistance, and leading actions to misconduct. Among institutional barriers, there was an absence of palliative care wards, trained professionals, and resources.

Mechanization is when you arrive at the bedside and simply administer the medication; you don't take a word of comfort, of affection, even in touch, the patient feels the affection, the way we hold it, change the diaper, give a bath. And the elderly ends up being very stubborn, we have to do what he wants, and not everyone has patience. (T4)

Usually, the ward is not focused on only one care profile - in this case, the palliative. So, there are several specialties together with the patient in palliative care, so it is very complicated to have a care standard. (T12)

I think there are barriers because we have a vision that we have to cure patients. So it is very difficult, sometimes, to make joint decisions that are not curative. It seems that we will give up on the patient, that we will just try to relieve suffering and stop doing any diagnostic procedures. (M3)

We try in every way to offer good assistance to the patient, but some circumstances cause harm to the patient. Regarding these damages, I think that a low staff cannot give good 24-hour assistance to the patient, even though they know that the patient demands too much of good assistance, it isn't possible. The lack of material in the institution contributes to the lack of adequate assistance, but we all do or try to do the best we can to contribute, through planning, to good assistance. (N4)

\section{Subcategory 3 - Exposing the influences that the family can have on the elderly's autonomy}

Subcategory 3 portrays the influence of the family on the elderly's autonomy, which can occur in different situations, whether in the role of the professional who seeks to defend the elderly's autonomy, whether by interceding for their autonomy or by working together with professionals, collaborating with nursing care.

The family interferes a lot, sometimes, even in the closing of decision making. The family may even want the patient not to be disturbed, but when he is dying, he says, "for the love of God, do something," inducing doctors to make decisions [...]. We received a lot of guidance from the family member who has already received information from the doctor. (T6)

This lack of instruction by the family member, in a way, interferes with the patient's autonomy, as he may not want a certain thing, but the family member makes decisions for the patient. (N10)

The essential is that the family is oriented and, thus, participative. A family that understands what is happening, because sometimes you can promote the patient's autonomy, and then appear the children who do not agree with any of that. (T8)

However, it is worth mentioning the family's participation in supporting and helping the elderly when debilitated and with physical disabilities. In addition to the condition of the oriented and participatory family, there is the importance of a respectful 
family, without overlapping the elderly's autonomy when they are able to exercise it.

The family member is present with the proposal to help when they need to call nursing for some care, for example, because most of the time, the elderly are unable to get up and call nursing for more immediate care. (N2)

\section{Subcategory 4 - Perceiving elderly's autonomy as a veiled and violated right}

Subcategory 4 reveals that the elderly's autonomy may not be exercised or defended. Such a violation can happen due to family members' actions, as well as actions or omissions by health professionals. Also, due to vulnerability and the clinical health condition, the elderly do not participate in decision-making.

The elderly should have their autonomy respected regardless of whether they are in a phase of finitude or not, but what we see in practice often differs from this. We see that sometimes because he spends a period with an altered level of consciousness, he is no longer seen as someone who can answer for his mental capacity. Often autonomy is not respected, everything is communicated to the family, and the relative decides on the health status of the elderly. Sometimes he is not even aware of the disease, and, with that, he ends up not being able to give an opinion, not having the right to choose about his treatment. (N9)

Often he has no autonomy because when he gets here he is already very weak and no longer has the ability to move around alone, take a shower, eat and sometimes, because of being in the terminal phase or even in palliative care, he already loses it a little, because he is more weakened by the state of the disease that makes him depressed [...]. We sometimes speak for the person, and with that, we interfere a little in autonomy and end up being invasive. We should ask if the person really wants it that way. He even has the right to speak, but sometimes we want to act, we want to help, we end up taking some of his autonomy. (T15)

\section{DISCUSSION}

Outlining the discussion about elderly's autonomy on the terminality of life, the data show the need to focus on the aspects of care models, work organization and power relationships that permeate the hospital environment since they can interfere in the process of decision-making, nurses' attitudes and practices and family participation.

Many health institutions maintain the administration of services under the influence of the biomedical care model instituted in the late 18th century, which has the following main characteristics: being curative and hospital-centered; focus on doctors the administration and decision-making about therapies and aiming at disease control and the medicalization of life ${ }^{(2,4)}$. Thus, the biomedical model affects the organization of health practice and limits or nullifies the professional autonomy of nurses ${ }^{(6-7)}$.

Among the dilemmas of this model, we highlight the increase in the elderly population, which is invariably accompanied by the high incidence of NCDs. In the face of a diagnosis that threatens the continuity of an elderly's life, it is necessary to review the context and the care planning, since the orientation of the practice exclusively by the cure paradigm, to the detriment of the care paradigm, causes exacerbation of suffering, anguish, dysthanasia, in addition to threatening to collapse the Brazilian health system ${ }^{(2)}$.

This understanding leads to reflection on Field Note 1, with emphasis on the procrastinated clinical evaluation of the older woman and the risk of non-continuity of care concerning the choice of the subcutaneous route for medication administration and pain control, as it could be an isolated action, out of the routine, on the night shift, based only on the experience of a professional and not on the assistance model. Notwithstanding, we noted the role of the nurse in defending the older woman's autonomy, being conditions, for example, proactive posture, knowledge, competences, and abilities, with emphasis on communication, professional experience, and adequate assessment of the patient's needs.

This assessment, which must be cyclical and dynamic, with continuous reassessments throughout the shift, specific to the nursing process, is essential to defend elderly's autonomy, as well as to recognize limited autonomy and act in favor of harm reduction and preservation of the person's dignity, with a clear sense of intervention for protection and following the bioethics of protection ${ }^{(3,7-8)}$.

The bioethics of protection, from the methodological point of view, can be understood as a tool to interact with distinct knowledge in respect for human rights and the common concern with the quality of life. "It addresses, in particular, health problems, focusing on individuals and populations affected in their health and well-being in a meaningful way," as in the case of hospitalized elderly, who, by the functional decline caused by diseases, advanced age, and hospitalization, are "susceptible" and "vulnerable"(8).

Thus, based on the control of the biomedical model under health organizations, especially the hospital, and under the work process, we alert to the weakened and insufficient empowerment of the elderly for self-government in this context ${ }^{(8-9)}$. This reality should guide the practice of nurses in defense of the patient's rights as a moral and ethical commitment, qualifying care for the benefit of the patient and the profession. Strengthening the patient's role strengthens the nurse's social role.

However, among the other factors that interfere in this practice, the following stand out: work overload; human resources deficit; lack of knowledge, with emphasis on palliative care; little professional autonomy; difficulty in communication and interpersonal relationships; feeling of helplessness; and lack of institutional support ${ }^{(7,9)}$.

The nurses participating in the study, because they had the stability of the employment relationship as public servants, did not indicate as a negative factor the fear of losing their job. But, the many needs of the services and the precariousness of work picture other challenges. Such challenges interfere in this practice and cause moral suffering, submissions, and conflicts, which can involve political issues.

It is noteworthy that professional overload generates distance between the staff, patients and family members, noises in communication, causing false hopes and mistrust on the part of the 
family, since it can perceive therapeutic futility in a way and force the staff to deviate from the principles of palliative care, including the elderly's autonomy ${ }^{(10-11)}$. This bias of understanding can expose the elderly, even if starting from decisions with benevolent intentions, because it does not favor the fulfillment of their desires and wills.

Thus, the importance of assuming the family as a care unit stands out, and it should be assisted by the health staff, including the nurse, in meeting their needs. In this sense, it is necessary to extend to the family the right to be continuously informed, reducing the possibilities of violation of elderly's autonomy. This referral bumps into all the conditioning factors mentioned, with emphasis on the lack of knowledge about palliative care.

Little scientific evidence includes innovative ways of dealing with the aging of the population and its demands since it is affected by a NCD and requires palliative care ${ }^{(12)}$. Moreover, the $21 \mathrm{st}$ century lacks new forms of organization of health services that are inclusive and based on interdisciplinarity. The accelerated demographic transition in developing countries is accompanied by the increasing complexity of the care process, given the capacity that science and technology seek to demonstrate in controlling life, which, in many situations of terminality, does not align with people's right to a dignified life.

In this scenario, nurses can play an indispensable role in the management of care for the elderly in moments involving dilemmas around mortality and the process of dying. In the predominant biomedical model, especially in the context of the hospital, nurses should seek to take advantage of opportunities to strengthen their exercise of power to make decisions, using the differential of constant presence and sensitivity to perceive the extrinsic and intrinsic needs of the elderly, especially in the transition to exclusive palliative care. This constant presence also contributes to the family participate and keep them informed, bringing them as collaborators to nursing care and defenders of elderly's autonomy, contributing to assert their will in the case of the transfer of guardianship ${ }^{(13)}$.

The importance of nurses' participation in teamwork and design of conduct was evidenced in the statements and observation, with objectives based mostly on the maintenance of the elderly's comfort. Thus, based on information that emerges from clinical practice, through the application of the nursing process, clinical reasoning, and ethical care, nurses can guide better choices and list appropriate actions in the care plan, as well as feel empowered at the heart of the exercise of their profession.

Contemporary care models focus their objectives on health prevention and promotion, thus concentrating greater efforts on low and medium complexity care, using light and low-cost technology, since it is possible to avoid most communicable diseases and non-transmissible. Moreover, once a chronic disease has a chronic disease, actions guided by models such as these aim to promote quality of life, reduce damage, and maintain the functional capacity of the elderly. Based on the antagonism to the biomedical model, we state that this paradigm of care expands the professional autonomy of nurses ${ }^{(2,7)}$.

This statement stems from the evidence in practice because although the biomedical model is predominant, it is precisely outside the hospital that there is greater professional autonomy of nurses, as in Primary Health Care, especially in the Estratégia Saúde da Família (Family Health Strategy) of, childbirth care and the field of mental health. However, particularly due to the deficiency of palliative care provision in the health care network, we highlight the hospital-centered character of the biomedical model with prolonged hospitalizations, high occupation of intensive care beds, and death in the hospital.

The failure to manage care for the elderly with NCDs in Primary Health Care, from the perspective of palliative care, interferes, therefore, in defending their autonomy - for example, in choosing means and place for their death. Thus, as exposed by the study participants, once hospitalized, the functional decline of the elderly can prevent them from understanding their rights. Moreover, if the issues relating to the dying process have not been dealt with before, it will be difficult, even for the family, to defend their autonomy, because itself, in the crisis, can be convinced by the doctor about the power of medicine and accept the futile therapies so as not to be failed in the face of death. It is in this context that the majority of nurses seek to safeguard the comfort and dignity of the elderly.

In the course of chronic disease of the elderly, three types of end of life stand out: rapid decline, gradual decline with episodes of decompensation, and slow and progressive decline. We emphasized that palliative care is not limited to terminality, and this increases the possibility of establishing a relationship of trust between the staff, patient, and family, avoiding unnecessary hospitalizations, meeting the care demands of the elderly of which requires the support of a home care service ${ }^{(14)}$. This service does not need to rely on specialists, but rather prioritize the general practitioner or family doctor, as well as the nurse in the management of this care ${ }^{(2)}$.

Professional training is a challenge for palliative care and defense of the elderly's autonomy on the terminality of life. Whatever the type of end of life and its manifestations, the elderly, or even their family, commonly deposit in the doctor all the power of decision, in complete confidence in the embodiment of knowledge. Furthermore, if the biomedical model guides these professionals, they may incur measures to maintain life at any cost and, thus, condition the care plan of all other members of the health staff based on this paradigm ${ }^{(15-16)}$.

Although the essence of nursing practice is care - that is, emancipation to promote comfort and quality of life - to have as its axis contemporary care models, to act in scenarios that can expand professional autonomy, as well as to know the prognosis of the patient and the proposals of the therapies are conditions that contribute to the actions in defense of the patient and application of palliative care ${ }^{(17)}$.

\section{Study Limitations}

According to the object of study, the choice of the scenario is recognized as a limitation, because it is a public institution of health care and, thus, does not confer on nurses the risk of losing their job and interfering in the professional posture to avoid conflicts or be misinterpreted. Another limiting aspect refers to the fact of being a university hospital, a medium in which professional autonomy can be more respected, considering the presence of academic values in practice scenarios. 
As the research applied GT, one cannot fail to point out as a limitation the aspect referring to the composition of the sample groups since family members, other health professionals, or even the elderly did not participate in the study. With this, there is a need for new scientific productions on the theme, including other participants.

\section{Contributions to nursing, health, or public policy fields}

The contributions are to guide health policies for the end of life; emphasize the need to change the orientation of care models, by increasing the number of elderly with NCDs and, thus, expanding care outside the hospital. Furthermore, recognizing the conditioning factors for the defense of the elderly's autonomy contributes to nurses contextualizing the practice and making efforts to maintain professional identity and quality of care.

\section{FINAL CONSIDERATIONS}

Even in the face of growing production of knowledge and efficient instruments for planning patient care, nurses' actions to promote patient rights are limited, especially in the area of palliative care.

The subjugation of the technical and scientific capacity of nurses linked to labor, political, social, and economic issues leads them to exercise little autonomy in hospital environments and to suffer morally. In addition to centralizing decisions, the presence of a hierarchical model hinders communication between professionals, reduces the quality of care, affects job satisfaction, and generates conflicts among professionals.

The role of nurses in benefiting the patient's autonomy comprises an essential ethical component for the practice of nurses. It is necessary to understand the meaning of this practice, its scope, and implications, considering the benefits capable of being generated to the patient and the profession.

Sincere communication and participation of the interdisciplinary staff are essential for the personification of the individual as subject to rights and an active participant in the construction of their health/disease process as well as of decisions about their treatment. This understanding is consistent with both the legal assumptions of the Brazilian legislative framework and the nursing profession and with the principles of bioethics of protection and palliative care.

\section{FUNDING}

This study was carried out with the support of the Coordination for Improvement of Higher Education Personnel - Brazil (CAPES - Coordenação de Aperfeiçoamento de Pessoal de Nível Superior) - Financing Code 001.

\section{REFERENCES}

1. Organização Mundial da Saúde (OMS). Relatório Mundial de Envelhecimento e Saúde. Suíça; 2015.

2. Veras R. Caring Senior: a Brazilian health model with emphasis at light care levels. Rev Bras Geriatr Gerontol. [Internet]. 2018 [cited 2018 Oct 17];21(3):360-6. Available from: http://www.scielo.br/pdf/rbgg/v21n3/1809-9823-rbgg-21-03-00360.pdf

3. McNally M, Lahey W. Frailty's place in ethics and law: some thoughts on equality and autonomy and on limits and possibilities for aging citizens. Interdiscip Top Gerontol Geriatr. 2015;41:174-85. doi: 10.1159/000381235

4. Niemeyer-Guimarães M, Schramm FR. The exercise of autonomy by older cancer patients in palliative care: the biotechnoscientific and biopolitical paradigms and the bioethics of protection. Palliat Care. 2017;9:1-6. doi: 10.1177/1178224216684831

5. Corbin J, Strauss A. Basics of qualitative research: techniques and procedures for developing Grounded Theory. California: SAGE; 2015.

6. Paiva FCL, Almeida Jr JJ, Damásio AC. Ética em cuidados paliativos: concepções sobre o fim da vida. Rev Bioét[Internet]. 2014 [cited 2017 Dec 10];22(3):550-60. Available from: http://www.scielo.br/pdf/bioet/v22n3/v22n3a19.pdf

7. Melo CMM, Florentino TC, Mascarenhas NB, Macedo KS, Silva MC, Mascarenhas SN. Autonomia profissional da enfermeira: algumas reflexões. Esc Anna Nery [Internet]. 2016 [cited 2017 Oct 12];20(4):e20160085. Available from: http://www.scielo.br/pdf/ean/v20n4/1414-8145-ean-20-04-20160085.pdf

8. Schramm FR. A bioética de proteção: uma ferramenta para a avaliação das práticas sanitárias? Ciên Saúde Colet[Internet]. 2017 [cited 2018 Oct 18];22(5):1531-8. Available from: http://www.scielo.br/pdf/csc/v22n5/1413-8123-csc-22-05-1531.pdf

9. Tomaschewski-Barlem JG, Lunardi VL, Barlem ELD. Advocacia do paciente na enfermagem: barreiras, facilitadores e possíveis implicações. Texto Contexto Enferm[Internet]. 2017 [cited 2018 Apr 20];26(3):e0100014. Available from: http://www.scielo.br/pdf/tce/v26n3/0104-0707tce-26-03-e0100014.pdf

10. Morata L. An evolutionary concept analysis of futility in health care. J Adv Nurs. 2018;74(6):1289-1300. doi: 10.1111/jan.13526

11. Partanen E, Lemetti T, Haavisto E. Participation of relatives in the care of cancer patients in hospital-A scoping review. Eur J Cancer Care (Engl). 2018;27(2):e12821. doi: 10.1111/ecc.12821

12. Pesut B, Hooper B, Jacobsen M, Nielsen B, Falk M, O'Connor BP. Nurse-led navigation to provide early palliative care in rural areas: a pilot study. BMC Palliat Care. 2017; 16:37. doi 10.1186/s12904-017-0211-2

13. Broom A, Kirby E, Good P, Lwin Z. Nursing futility, managing medicine: Nurses' perspectives on the transition from life-prolonging to palliative care. Health. 2016;20(6):653-70.doi: 10.1177/1363459315595845

14. Poulalhon C, Rotelli-Bihet L, Moine S, Fagot-Campagna A, Aubry R, Tuppin P. Use of hospital palliative care according to the place of death and disease one year before death in 2013: a French national observational study. BMC Palliat Care. 2018;17:75. doi.org/10.1186/s12904-018-0327-z 
15. Moir C, Roberts R, Martz K, Perry J, Tivis LJ. Communicating with patients and their families about palliative and end of fife: comfort and educational needs of Staff RNs. Int J Palliat Nurs. 2015;21(3):109-12. doi: 10.12968/ijpn.2015.21.3.109

16. Saunders C. Velai comigo - inspiração para uma vida em cuidados paliativos. Salvador: editor FSS; 2018.

17. Carvalho V. Sobre a identidade profissional na Enfermagem: reconsiderações pontuais em visão filosófica. Rev Bras Enferm[Internet]. 2013 [cited 2018 Oct 20];66(esp):24-32. Available from: http://www.scielo.br/pdf/reben/v66nspe/v66nspea03.pdf 